\title{
ANALISIS PENGETAHUAN LAPORAN KEUANGAN PADA UMKM INDUSTRI KONVEKSI DI SALATIGA
}

\author{
Oleh: \\ Endang Purwanti \\ Dosen Tetap STIE AMA Salatiga
}

\begin{abstract}
Abstrak
Keberadaan perkembangan UMKM industri konveksi di Salatiga cukup berarti apalagi yang mendapat perhatian dari pemerintah sebagai penggerak perekonomian di Negara ini,tetapi sektor ini belum mampu menjadi sektor yang mandiri dan menjadi tumpuan perekoomian nasional.Perkembangan UMKM terhambat oleh berbagai permasalahan.Permasalahan permodalan menjadi permasalahan yang klasik yang belum bisa terpecahkan. Sebagi seorang wirausaha yang baik seharusnya membutuhkan pengetahuan laporan keuangan pada usahanya. Oleh karena itu penelitian ini bertujuan untuk mengetahui seperti apa pengetahuan laporan keuangan pada UMKM industri konveksi di Salatiga. Sampel pada penelitian ini diambil dengan sebanyak 25 responden. Pengumpulan data pada penelitian ini dilakukan dengan wawancara dan dengan menyebarkan kuisioner terbuka. Teknik analisis data pada penelitian ini menggunakan distribusi frekuensi. Dari hasil penelitian ditemukan bahwa pengetahuan laporan keuangan responden yaiu wirausaha UMKM industri konveksi di Salatiga masih sebatas mengenali laporan keuangan secara dasar. Mendasarnya pengetahuan laporan keuangan responden dikarenakan oleh beberapa alasan salah satunya adalah pendidikan mengenali laporan keuangan yang sebagian besar belum mereka peroleh baik dari pendidikan formal maupun informal. Responden beranggapan bahwa pengetahuan laporan keuangan yang dimiliki dirasa cukup memadai untuk membantu proses keberlangsunangan usaha meskipun hanya sebatas membayar tagihan, gaji pegawainya, belum mapu membuat laporan keuangan sebagai ukuran kinerja usahanya.
\end{abstract}

Kata Kunci : Pengetahuan Laporan Keuangan 


\section{PENDAHULUAN}

Meskipun sektor UMKM telah ada sejak era prakolonial dan terus berkembang hingga saat ini, bahkan terbukti menjadi katup pengaman Indonesia mengalami krisis ekonomi, tetapi sektor ini belum mampu menjadi sektor yang mandiri dan menjadi tumpuan perekonomian nasional.

Berbagai masalah pokok yang dihadapi UMKM dengan menggolongkannya menjadi masalah internal dan masalah eksternal. Masalah internal UMKM berfokus pada rendahnya kualitas sumber daya manusia, lemahnya jaringan usaha dan kemampuan penetrasi pasar, kurangnya permodalan, masalah tehnologi, serta masalah organisasi dan manajemen. Kualitas sumber daya manusia memang menjadi faktor yang penting dalam pengembangan sebuah usaha. Dalam kasus UMKM harus diakui bahwa sebagian besar pelaku UMKM masih dihadapkan pada berbagai kendala yang belum bisa ditangani dengan baik, misalnya tingkat kemampuan, ketrampilan, keahlian dan profesionalisme sumber daya manusia.(Rachmawan Bidiarto dkk,2015).

Permasalahan permodalan menjadi permasalahan klasik, aksessibilitas pelaku UMKM terhadap sumber-sumber permodalan dari lembaga perbankan dapat dikatakan rendah.Meskipun banyak skim kredit khusus bagi pengusaha kecil, banyak UMKM yang tidak pernah mendapatkan kredit dari bank atau lembaga keuangan lainnya.Keengganan pengusaha UMKM untuk memanfatkan pinjaman dimungkinkan karena mereka sama sekali tidak tahu tentang dana pinjaman atau ada yang mengetahui sempat mengajukan dengan prosedur yang berbelit.Sering kali pengajuan pinjaman ditolak karena persyaratan adminitrasi (Effendi dkk,2012).Dari sudut pandang perbankan, pelaku UMKM dinilai tidak layak karena tidak memiliki agunan dan kemampuan mengembalikan pinjaman yang rendah.Karena kebutuhan permodalan menjadi problem yang mendesak, tidak sedikit pengusaha mikro dan sektor informal mengambil jala pragmatis dengan mencari permodalan dari rentenir, pelepas uang.

Pola kredit yang dijalankan rentenir sangat praktis dan sederhana, tidak memperhatikan asas-asas prudential (kahati-hatian). Namun disisi lain UMKM harus menanggung suku bunga yang tinggi. Jasa informal ini tidak memacu tumbuhnya sistem administrasi yang tertib dan baik serta tidak mendidik perilaku berhemat 
kepada mayarakat penerima kredit. Rendahnya kualitas laporan keuangan bisa dikarenakan pada umumnya UMKM merupakan perusahaan keluarga yang cenderung belum memisahkan administrasi keuangan keluarga dengan keuangan perusahaan, hal ini menyebabkan kesulitan bagi perbankan untuk mengetahui seberapa jauh dan seberapa besar kemampuan membayar UMKM atas kredit yang mereka dapatkan.

Beberapa penelitian sebelumnya yang berkenaan dengan penerapan pencatatan akuntansi banyak dilakukan pada UMKM, seperti penelitian Nitisastro (2009) menjelaskan mengenai penggunaan business technology dalam penyediaan laporan keuangan perusahaan dan dampak terhadap perkembangan usaha di UMKM dengan hasil SDM yang rendah sebagian tidak menyadari akan pentingnya akuntansi dan penerapan akuntansi. Penelitian lain yang menjelaskan tentang penerapan pencatatan akuntansi pada UMKM dilakukan oleh Arifin (2010) yang menemukan bahwa di Salatiga, UMKM menerapkan akuntansi masih sederhana. Amanah (2012) juga menemukan bahwa pada UMKM sebagian besar belum menerapkan akuntansi. Sementara Myer dalam Munawir ( 2002) mengatakan bahwa laporan keuangan adalah dua daftar yang disusun oleh akuntan pada akhir periode untuk suatu perusahaan. Laporan keuangan menjadi penting karena memberikan input (informasi) yang bisa dipakai untuk pengambilan keputusan. Kedua daftar itu adalah daftar neraca atau daftar posisi keuangan dan daftar pendapatan atau daftar rugi laba.

Menurut S Mulyawan ( 2015 ) Laporan keuangan merupakan alat penguji dari pekerjaan bagian pembukuan yag digunakan untuk menentukan atau menilai posisi keuangan perusahaan.Oleh karena itu dari paparan di atas dapat dirumuskan persoalan utama dalam penelitian ini yaitu, seperti apa pengetahuan laporan keuangan UMKM di Salatiga

\section{Rumusan Masalah}

Dari paparan diatas maka dirumuskan masalah penelitian : Bagaimana Pengetahuan Laporan Keuangan Pada UMKM Industri Konveksi di Salatiga ?

\section{Tujuan Dan Manfaat Penelitian}

Untuk mengetahui bagaimana Pengetahuan Laporan Keuangan Pada UMKM Industri Konveksi di Salatiga.Manfaat penelitian ini bagi UMKM dapat mengerti arti pentingnya laporan keuangan sehingga dapat untuk mempermudah melakukan pengembangan UMKM terutama dari permodalan. 


\section{LANDASAN TEORITIS}

\section{Pengertian UMKM (Usaha Mikro, Kecil dan Menengah)}

Berdasarkan Undang-Undang Republik Indonesia No 20 Tahun 2008 tentang Usaha Mikro, Kecil dan Menengah (UMKM) dalam (Rachmawan, dkk,2015)

Usaha mikro adalah usaha produktif milik orang perorang dan atau badan usaha perorangan yang memenuhi kriteria usaha mikro, memiliki kekayaan bersih paling banyak Rp 50.000.000 (lima puluh juta rupiah) tidak termasuk tanah dan bangunan tempat usaha; atau memiliki hasil penjualan tahunan paling banyak Rp. 300.000.000,00 (tiga ratus juta rupiah).

Usaha kecil adalah usaha ekonomi produktif yang berdiri sendiri, dilakukan oleh orang perorang atau badan usaha yang bukan merupakan anak perusahaan atau bukan cabang perusahaan yang dimiliki, dikuasai, atau menjadi bagian baik langsung maupun tidak langsung dari usaha menengah atau usaha besar yang memenuhi kriteria usaha kecil. Memiliki kekayaan bersih lebih dari Rp. 50.000.000,00 , tidak termasuk tanah dan bangunan tempat usaha; atau memiliki hasil penjualan tahunan lebih dari Rp. 300.000.000,00 sampai dengan paling banyak Rp. 2.500.000.000,00

Usaha menengah adalah usaha ekonomi produktif yang berdiri sendiri, yang dilakukan oleh orang perorang atau badan usaha yang bukan merupakan anak perusahaan atau bukan cabang perusahaan yang dimiliki, dikuasai, atau menjadi bagian baik langsung maupun tidak langsung dengan usaha kecil atau usaha besar.Memiliki kekayaan bersih lebih dari Rp. 500.000.000,00 sampai dengan paling banyak Rp. 10.000.000.000,00 tidak termasuk tanah dan bangunan tempat usaha; atau memiliki hasil penjualan tahunan lebih dari Rp. 2.500.000.000,00 sampai dengan paling banyak Rp. 50.000.000.000,00.

Sedangkan Badan Pusat Statistik (BPS) menggolongkan menjadi empat berdasrkan jumlah tenaga kerja yang dimiliki. Yang pertama adalah industri rumah tangga apabila memiliki tenaga kerja antara satu sampai empat orang. Kedua adalah industri kecil dengan jumlah tenaga kerja antara lima sampai sembilan orang. Ketiga adalah industri sedang/menengah apabila memilki tenaga kerjaantara 10 samapai 99 orang. Terakhir adalah industri besar apabila memiliki jumlah tenaga kerja lebih dari 100 orang.Dalam konteks pengembangan ekonomi rakyat, sektor UMKM menjadi titik sentral didalamnya. Berdasarkan data BPS dan Kementrian Koperasi dan Usaha 
Kecil Menengah, dari total tenaga kerja usaha besar dan usaha kecil pada tahun 2010 sebanyak 102,2 juta orang, sekitar 99,4 juta orang $(97,22 \%)$ berada pada sektor usaha Mikro, Kecil dan Menengah (UMKM). Data ini menunjukan bahwa sektor UMKM memiliki kontribusi dalam penyerapan tenaga kerja.Masalah kekurangan kapital (investasi) yang dihadapi dipecahkan dengan pola investasi yang padat tenaga kerja. Data empiris menunjukan bahwa dengan investasi terbatas, unit usaha ekonomi rakyat dapat menciptakan lebih banyak unit usaha dan juga kesempatan kerja (Hamid, 2005)

Ada tiga jenis usaha yang bisa dilakukan oleh UMKM untuk menghasilkan laba: 1.Usaha Manufaktur yaitu usaha manufaktur ialah usaha yang mengubah input dasar menjadi produk yang bisa dijual kepada konsumen.Misalnya konveksi yang menghasilkan pakaian jadi. 2.Usaha Dagang yaitu usaha dagang ialah usaha yang menjual produk kepada konsumen.3.Usaha Jasa yaitu usaha jasa merupakan usaha yangmenghasilkan jasa, bukan menghasilkan produk atau barang untuk konsumen.

\section{Pengertian Laporan Keuangan}

Menurut S Mulyawan ( 2015 ) Laporan keuangan merupakan alat penguji dari pekerjaan bagian pembukuan yang digunakan untuk menentukan atau menilai posisi keuangan perusahaan. Dari laporan keuangan, dapat diketahui posisi keuangan perusahaan serta hasil-hasil yag telah dicapai perusahaan. Sebagaimana dikemukakan oleh Mamduh M Hanafi ( 2004) pada umumnya laporan keuangan yang sering digunakan terdiri atas:1.Laporan Keuangan Neraca yang menggambarkan posisi kekayaan yang dimiliki oleh perusahaan pada waktu tertentu, neraca keuangan biasanya dinyatakan per tanggal tertentu.Neraca dibagi kedalam dua bagian sisi kiri yang menyajikan aset yang dimiliki perusahaan, sisi kanan menyajikan sumber dana yang dipakai untuk memperoleh aset tersebut. Untuk setiap sisi neraca disusun atau diurutkan berdasarkan likuiditas aset tersebut. Likuiditas yang dimaksud adalah kedekatan dengan kas. Karena itu kas ditempatkan pada baris pertama. Demikian juga dengan sisi kanan (pasiva) neraca. Kewajiban diurutkan dari utang dagang sampai modal saham. 2.Laporan Keuangan Laba Rugi meringkaskan aktivitas perusahaan selama periode tertentu.

Laporan laba rugi sering dianggap sebagai laporan yang palig penting dalam laporan tahunan. 3.Laporan Keuangan Arus Kas meringkas aliran kas masuk dan keluar perusahaan untuk jangka waktu tertentu. Laporan aliran kas diperlukan karena 
dalam beberapa situasi, laporan laba rugi tidak cukup akurat menggambarkan kondisi keuangan perusahaan.Menurut Munawir (2002) bentuk laporan keuangan terdiri dari neraca laporan laba rugi, laporan perubahan modal, laporan aliran kas.Laporan keuangan akan memberikan informasi mengenai profitabilitas, risiko, timing aliran kas, yang kesemua nya akan mempengaruhi harapan pihak-pihak yang berkepentingan.

Harapan tersebut pada nilai selanjutnya akan mempengaruhi nilai perusahaan.Sedangkan menurut Standart Akuntansi Keuangan Th 2012 laporan keuangan merupakan bagian dari proses pelaporan keuangan. Laporan keuangan yang lengkap biasanya meliputi neraca, laporan laba rugi, laporan perubahan posisi keuangan (yang dapat disajikan dalam berbagai cara misalnya, sebagai laporan arus kas, atau laporan arus dana), catatan dan laporan lain serta materi penjelasan yang merupakan bagian integral dari laporan keuangan. Tujuan laporan keuangan adalah menyediakan informasi yang menyangkut posisi keuangan, kinerja keuangan, serta posisi keuangan suatu entitas yang bermanfaat bagi sejumlah besar pengguna dalam pengambilan keputusan. Sedangkan menurut (Sutrisno,2008)

Laporan Keuangan merupakan hasil akhir dari proses akuntansi yang meliputi dua laporan utama yakni Neraca dan Laporan Rugi Laba. Laporan keuangan disusun dengan maksud untuk menyediakan informasi keuangan suatu perusahaan kepada pihak-pihak yang berkepentingan sebagai bahan pertimbangan di dalam mengambil keputusan. Pihak-pihak yang berkepentingan tersebut antara lain manajemen,pemilik, kreditor, investor, dan pemerintah.Menurut (Kasmir, 2002) salah satu pihak yang mempunyai kepentingan adalah kreditor yaitu pihak yang dapat memberikan kredit atau pinjaman yang dapat digunakan untuk modal kerja maupun untuk investasi. Salah satu aspek yang digunakan dalam penilaian kelayakan kredit adalah aspek keuangan, untuk menilai keuangan perusahaan yang dilihat dari laporan keuangan yaitu Neraca dan Laporan Rugi dan Laba yang tidak cukup satu tahun yang biasanya sampai tiga tahun, kondisi ini untuk melihat perkembangan usaha. Sedangkan menurut (Rachmat F \& Maya A,2004) aspek keuangan sangat menentukan kualitas usaha dan yang terpenting untuk menilai kemampuan berkembangnya usaha tersebut pada masa-masa mendatang serta untuk menilai kemampuan dalam membayar kreditnya. Titik berat 
penganilisian dilakukan terhadap Laporan Keuangan yang terdiri dari Neraca, Laba Rugi.

\section{Pengetahuan Laporan Keuangan}

Josoprijonggo (2009) yang membahas mengenai pemahaman pengetahuan mahasiswa mengenai obligasi dan penelitian pengetahuan pajak oleh Supramono dan Damayanti (2012). Dari penelitian di atas batasan-batasan istilah pengetahuan juga masih rancu antara pemahaman pengetahuan dan literasi, untuk itu penulis ingin memberikan batasan yang jelas mengenai pengetahuan laporan keuangan.

Pengetahuan mungkin tidak lebih hanya sekedar tahu hal-hal teknis yang memang harus diketahui tanpa adanya kemampuan untuk menangkap makna seperti halnya pemahaman (Sagala, 2005). Bakhtiar (2004) dalam penelitiannya mendefinisikan pengetahuan sebagai kepercayaan yang benar (knowledge is justified true belief). Pengetahuan tersebut bisa muncul dari semua hasil pemikiran manusia. Dengan demikian pengetahuan merupakan hasil proses dari usaha manusia untuk tahu (Josoprijonggo, 2009). Gunawan (2009) mengatakan pengetahuan adalah informasi yang didapat seseorang mengenai sesuatu yang diperoleh melalui pembelajaran, pemahaman dan pengalaman. Sesuatu akan informasi yang diperoleh tersebut dapat diterapkan dalam seluruh aspek karena dengan mengkomunikasikan dan mengaplikasikan pengetahuan diharapkan competitive advantage dapat dicapai (Hartanto, 2006).

Apabila dilihat dari ranah kognitif pengetahuan meliputi kemampuan intelektual yang terdiri dari pengetahuan atau ingatan, mengenali (Rahayu, 2012) pemahaman, aplikasi, analisis, dan evaluasi (Titisari, et., al, 2013). Selanjutnya ranah afektif pengetahuan berhubungan dengan emosi seperti perasaan, nilai, apresiasi, motivasi dan sikap. Terdapat lima kategori utama afektif dari yang paling sederhana sampai kompleks yaitu penerimaan, tanggapan, penghargaan, pengorganisasian, dan karakterisasi fenomena (Sukanti, 2011). Kemudian ranah psikomotorik pengetahuan mencakup yang berupa keterampilan fisik dan ketrampilan (motorik dan kemampuan bertindak) (Muhibbin, 2003).

Dalam pengertian terluas kata pemahaman hanya berarti penyampaian elease) informasi, tetapi para akuntan cenderung menggunakan kata ini dalam pengertian agak lebih terbatas, yaitu penyampaian informasi keuangan tentang suatu perusahaan 
di dalam laporan keuangan, biasanya termuat dalam laporan tahunan perusahaan. Istilah ini kadang dibatasi lebih jauh hingga hanya berarti informasi yang tidak dimuat dalam laporan keuangan itu sendiri.Banyaknya informasi yang harus diungkapkan sebagian tergantung dari keahlian pembaca. Informasi yang diungkapkan dalam laporan keuangan harus dapat dipahami oleh mereka yang mempunyai pengetahuan yang memadahi mengenai aktivitas ekonomi bisnis dan bisnis akuntansi serta mau mempelajari informasi tersebut dengan ketekunan yang wajar.Tingkatan pemahaman juga tergantung pada standar yang dianggap paling diinginkan.

Tiga konsep pemahaman yang biasanya diusulkan adalah pemahaman yang memadahi (adequate), wajar (fair), dan lengkap (full). Yang paling banyak digunakan dari ketiga pemahaman tersebut adalah pemahaman yang memadahi, tetapi pemahaman ini menyiratkan jumlah pemahaman minimum yang sejalan dengan tujuan negatif membuat laporan tersebut tidak menyesatkan. Wajar dan lengkap merupakan konsep yang lebih positif . Pemahaman yang menyiratkan suatu tujuan etika, yaitu memberikan perlakuan yang sama pada semua pembaca, pemahaman lengkap menyiratkan penyajian seluruh informasi yang relevan.

Bagi sebagian orang, pemahaman lengkap berarti penyajian informasi secara berlimpah, tetapi pendapat itu tidak tepat karena penyajian informasi yang selalu banyak akan membahayakan karena penyajian rincian yang tidak penting dapat menyembunyikan informasi yang signifikan serta membuat laporan keuangan sulit untuk ditafsirkan. Tetapi, pemahaman informasi yang signifikan bagi investor serta pihak-pihak lainnya haruslah memadahi, wajar dan lengkap,tidak ada perbedaan nyata antara konsep-konsep tersebut, semuanya haruslah digunakan. Proses pencatatan berarti mengumpulkan data transaksi secara kronologis, kemudian mengelompokkan dan menggolongkan dalam akun-akun agar lebih ringkas dan selanjutnya pengikhtisaran dari informasi yang telah digolongkan ke dalam bentuk laporan yang diinginkan pemakai (Soemarso, 2004).

Selain itu mengenali adanya siklus transaksi dalam kegiatan usaha juga termasuk dalam ranah kognitif, siklus tersebut di antaranya siklus pendapatan (revenue) yang merupakan aktivitas bisnis dan kegiatan yang terkait dengan penyediaan barang dan jasa ke para pelanggan dan menagih kas sebagai pembayaran dari penjualan-penjualan tersebut, siklus pengeluran (expenditure) merupakan 
kegiatan bisnis dan operasional pemrosesan data terkait yang berhubungan dengan pembelian serta pembayaran barang dan jasa, siklus penggajian sumber daya manusia (payroll) yaitu yang berhubungan dengan mengelola pegawai sampai membayar gaji pegawai, siklus produksi yang meliputi perancangan produk, perencanaan produksi dan operasi produksi, dan siklus keuangan yang mencakup kegiatan untuk mendapatkan dana dari investor dan kreditor (Romney, 2011).

Pengetahuan laporan keuangan juga menunjukkan sikap kesadaran akan pentingnya peran laporan keuangan bagi pengguna.Hal ini dikarenakan laporan kinerja usaha yang terpenting adalah laporan keuangan. Karena dengan laporan keuangan pihak kreditor dapat melihat perkembangan kinerja usaha dan dapat memperkirakan kinerja usaha di masa yang akan datang. Oleh sebab itu pengusaha kecil dan menengah harus memiliki kebiasaan untuk menyusun laporan keuangan sebagai salah satu cara pengembangan usahanya.

\section{METODE PENELITIAN}

\section{Populasi Dan Sampel}

Dalam penelitian ini diambil dari UMKM industri konveksi di Salatiga. Pertimbangan Salatiga sebagai objek penelitian adalah UMKM industri konveksi di Salatiga semakin terlihat perkembangannya. Populasi tersebut dilihat berdasarkan kriteria jenis usaha konveksi karena pelaku UMKM di Salatiga sebagian besar adalah usaha industri konveksi yang bergabung dalam kelompok usaha maju bersama berjumlah 30 UMKM.Yang menjadi sampel penelitian ini adalah seluruh anggota populasi berjumlah 30 UMKM yang bergabung dalam kelompok usaha maju bersama .Metode pegambilan sampel ini adalah metode sensus yaitu penelitian terhadap keseluruhan anggota populasi atau jumlah sampel sama dengan jumlah populasi.(Supramono Intiyas, 2003)

\section{Definisi Konsep Dan Definisi Operasional}

\section{Definisi Konsep}

\section{Laporan Keuangan}

Laporan Keuangan merupakan hasil akhir dari proses akuntansi yang meliputi dua laporan utama yakni Neraca dan Laporan Rugi Laba. Laporan keuangan disusun dengan maksud untuk menyediakan informasi keuangan suatu perusahaan kepada pihak-pihak yang berkepentingan sebagai bahan pertimbangan di dalam mengambil 
keputusan. Pihak-pihak yang berkepentingan tersebut antara lain manajemen,pemilik, kreditor, investor, dan pemerintah. (Sutrisno,2008)

\section{Pengetahuan Laporan Keuangan}

Gunawan (2009) mengatakan pengetahuan adalah informasi yang didapat seseorang mengenai sesuatu yang diperoleh melalui pembelajaran, pemahaman dan pengalaman.Pengetahuan laporan keuangan juga menunjukkan sikap kesadaran akan pentingnya peran laporan keuangan bagi pengguna.Hal ini dikarenakan laporan kinerja usaha yang terpenting adalah laporan keuangan. Karena dengan laporan keuangan pihak kreditor dapat melihat perkembangan kinerja usaha dan dapat memperkirakan kinerja usaha di masa yang akan datang.

\section{Definisi Operasional}

Pengukuran konsep merupakan suatu upaya untuk mengkaji dan melihat konsep yang abstrak secara empiris. Konsep-konsep perlu diidentifikasi secara tepat agar dapat dilakukan analisis secara tafsiran terhadap data yang diperoleh secara tepat (Ihalauw, 2003). Item-item tersebut digunakan untuk pertanyaan pada kuisioner. Item yang digunakan sebagai berikut :

\section{Pengetahuan Laporan Keuangan}

a. Pengetahuan mengenai Laporan Keuangan secara umum

b. Pengetahuan mengenai manfaat dan fungsi dari Laporan Keuangan

c. Pengetahuan yang dinilai dari kemampuan dan ketrampilan Laporan Keuangani dari latar belakang pendidikan

d. Pengetahuan mengenai jenis-jenis Laporan Keuangan

\section{Analisis data}

\section{Analisis Statistik Deskriptif}

Analisis data yang dipakai adalah pendekatan deskriptif. Analisis ini memberikan gambaran menyeluruh tentang pengetahuan laporan keuangan pada UMKM industri konveksi di Salatiga, sehingga dapat dilihat seperti apa pengetahuan laporan keuangan. Selanjutnya untuk mempermudah analisis data akan disajikan tabel distribusi frekuensi sederhana.

Data diperoleh melalui kuisioner dan wawancara yang secara langsung bertemu kepada pelaku UMKM Industri Konveksi di Salatiga. Dalam penelitian 
jumlah responden yang berhasil ditemui dan yang mengisi kuisioner secara lengkap sebanyak 25 responden.

\section{HASIL ANALISIS DAN PEMBAHASAN}

\section{Deskripsi Obyek Penelitian}

Desa Tingkir merupakan desa kecil dan asri yang terletak di perbatasan Kota Salatiga dan Kabupaten Semarang. Sekilas memang tidak ada yang istimewa dari desa ini. Hanya ada rumah-rumah penduduk, warung-warung kecil dan surau-surau. Sama sekali tidak ada yang menarik. tapi jangan salah sangka dulu, desa wisata tingkir lor memang bukan kawasan eco-tourism. Desa ini mendapat gelar'Desa Wisata” karena mayoritas penduduknya memiliki UMKM dalam bidang konveksi. Produksi merekapun dipasarkan ke beberapa daerah di Kalimantan, Sulawesi, Bali, dan Sumatera. Adanya sejumlah pelaku UMKM di bidang Konveksi, mendorong terbentuknya sebuah Kelompok Usaha Bersama (KUBE) dengan beranggotakan Tiga Puluh anggota yag memproduksi Konveksi yang bahan bakunya diperoleh dari lokal,mereka mengambil dari pabrik-pabrik sekitar Salatiga, namun bahan baku yang digunakan sebagian besar dari bahan yang reject, selain dari sekitar Salatiga ada juga yang mengambil bahan baku dari Bandung dan Solo.

\section{Deskripsi Data}

\section{Identitas Responden}

Dari jumlah 30 responden yang menjadi sampel penelitinan yang berhasil ditemui dan yang mengembalikan kuisioner secara lengkap berjumlah 25 responden.Ssejumlah 25 responden UMKM di Salatiga yang berhasil ditemui, sebagian besar responden berjenis kelamin wanita yaitu dengan presentase mencapai $76 \%$ atau 19 responden. Dilihat dari umur responden sebagian besar berumur 39-45 tahun, sebanyak 12 responden atau $48 \%$ berada pada range tersebut. Terkait dengan pendidikan terbukti sebagian besar responden berpendidikan terakhir SMA dengan total 20 responden atau mencapai $80 \%$. Terlihat juga responden yang berpendidikan S1 ada 1 responden (4\%) Selanjutnya untuk responden lain berpendidikan SMP. Banyaknya responden yang berjenis kelamin wanita dikarenakan produk yang dihasilkan adalah konveksi berkaitan dengan fashion. Dilihat dari umur sebagian besar responden berumur produktif dan berpendidikan mayoritas SMA kondisi ini disebabkan karena sebagian besar responden tidak melajutkan pendidika yang lebih 
tinggi namun mereka memilih untuk berwirausaha, dorongan untuk berani berwirausaha salah satu penyebabnya karena Salatiga khususnya desa Tingkir dijadikan desa wisata yang sebagian besar pelaku UMKM di bidang konveksi. Pengalaman usaha responden sebagian besar diatas 10 tahun yaitu sejumlah 14 responden atau $56 \%$, sedangkan $4 \%$ yang perpengalaman dalam wirausaha bidang konveksi selama 5 tahun.

\section{Perkembangan Usaha}

Jumlah karyawan sebagian besar UMKM industri konveksi di Salatiga merupakan usaha perorangan yang tidak banyak memiliki karyawan. Hal tersebut terlihat ada sebanyak 23 responden (92\%) yang pada saat berdiri hanya memiliki karyawan 1-5 orang saja. Namun dilihat perkembangannya,UMKM koveksi di Salatiga mempunyai karyawan 1-5 orang menurun menjadi 21 responden atau 84\%.Dilihat dari modal usaha pada saat usaha berdiri ada 2 responden atau $8 \%$ mengaku memiliki modal diatas 31 juta rupiah. Namun pada perkembangannya ada 6 responden atau $24 \%$ yang modalnya diatas 31 juta rupiah, dengan demikian ada peningkatan kepemilikan modal, namun masih ada responden masih dalam range berkisar 1 jt sampai 10 juta .

Selanjutnya dari omzet yang diperoleh responden sebagai pelaku UMKM industri konveksi pada range omzet 1 jt sampai 10 jt mengalami penurunan dari 13 responden atau $52 \%$ penurunan ini dikarenakan sebagian responden mengalami kenaikan omzet ke range 11 jt sampai 20 jtini terbukti pada range tersebut pada saat mulai usaha 8 responden atau $32 \%$ yang mendapatkan omzet pada range tersebut namun saat ini mengalami kenaikan menjadi 16 responden atau $64 \%$ kenaikan omzet yang diperoleh belum maksimal artinya omzet yang diperoleh belum sampai diatas 31 jt, terbukti pada saat awal berdiri hanya ada satu responden atau $4 \%$ yang mendapatkan omzet lebih dari 31 jt rupiah, kondisi saat ini masih tetap satu responden atau $4 \%$.

Hal ini menunjukkan benar adanya bahwa UMKM sebagai pengatup perekonomian di Indonesia harus diakui bahwa sebagian besar pelaku UMKM masih dihadapkan pada berbagai kendala yang belum bisa ditangani dengan baik. (Rachmawan Bidiarto dkk,2015). Dalam kaitannya pada sumber pendanaan, pada awal berdirinya usaha hanya ada 4 responden atau $16 \%$ yang berani secara langsung 
mendapatkan pendanaan modal dari pihak Bank, berjalannya usaha saat ini ada kenaikkan menjadi 7 responden atau $28 \%$ yang mendapatkan pendanaan modal dari pihak Bank.

Namun sebenarnya ada sisi lain dalam temuan penelitian ini, tidak adanya bantuan sumber pendanaan dari pemerintah menjadi bukti bahwa sebenarnya pemerintah belum secara keseluruhan benar-benar mendukung dalam hal pendanaan padahal saat ini pemerintah sedang serius dan gencar menanggapi perkembangan UMKM. Temuan lain dalam penilitian ini bahwa sumber dana yang tersbesar berasal dari pribadi saat ini masih tinggi yaitu 18 responden atau $72 \%$, hal ini membuktikan bahwa perkembangan umkm masih terkendala pada permasalahan permodalan yang belum bisa teratasi.

\section{Pembahasan Pengetahuan Laporan Keuangan}

Tabel.1

Pengetahuan Laporan Keuangan

\begin{tabular}{|c|c|c|c|}
\hline & & $\underset{(*)}{\text { Jumlah }}$ & $\begin{array}{l}\text { Presentase } \\
(\%)\end{array}$ \\
\hline \multirow{6}{*}{$\begin{array}{l}\text { a. Pengetahuan } \\
\text { Mengenai } \\
\text { Laporan } \\
\text { Keuangan Secara } \\
\text { Umum }\end{array}$} & \multicolumn{3}{|c|}{ Apakah Laporan Keuangan itu? } \\
\hline & $\begin{array}{l}\text { Perhitungan yang berkaitan } \\
\text { dengan keuangan }\end{array}$ & 2 & $8 \%$ \\
\hline & Pembukuan Keuangan & 16 & $64 \%$ \\
\hline & Laporan Keuangan & 2 & $8 \%$ \\
\hline & Aliran Kas & 5 & $20 \%$ \\
\hline & Jumlah & 25 & $100.0 \%$ \\
\hline \multirow{6}{*}{$\begin{array}{l}\text { b. Pengetahuan } \\
\text { Mengenai } \\
\text { Manfaat dan } \\
\text { Fungsi Laporan } \\
\text { Keuangan }\end{array}$} & \multicolumn{3}{|c|}{ Apa manfaat dan fungsi Laporan Keuangan? } \\
\hline & Mengelola keuangan usaha & 3 & $12 \%$ \\
\hline & Mengontrol keuangan usaha & 3 & $12 \%$ \\
\hline & $\begin{array}{l}\text { Mengetahui pemasukan, } \\
\text { pengeluaran dan laba }\end{array}$ & 18 & $72 \%$ \\
\hline & Pengambilan Keputusan & 1 & $4 \%$ \\
\hline & Jumlah & 25 & $100.0 \%$ \\
\hline \multirow{8}{*}{$\begin{array}{l}\text { c. } \text { Pengetahuan } \\
\text { dilihat dari latar } \\
\text { belakang } \\
\text { pendidikan }\end{array}$} & \multicolumn{3}{|c|}{$\begin{array}{c}\text { Apakah Anda mengetahui banyak hal laporan } \\
\text { Keauangan? }\end{array}$} \\
\hline & $\mathrm{Ya}$ & 11 & $44 \%$ \\
\hline & Tidak & 14 & $56 \%$ \\
\hline & Jumlah & 25 & $100.0 \%$ \\
\hline & \multicolumn{3}{|c|}{$\begin{array}{l}\text { Jika Ya, di mana Anda mendapatkan pengetahuan } \\
\text { laporan keuangan? }\end{array}$} \\
\hline & Formal & 3 & $27 \%$ \\
\hline & Informal & 8 & $73 \%$ \\
\hline & Jumlah & 11 & $100.0 \%$ \\
\hline d. Pengetahuan & \multicolumn{3}{|c|}{ Dalam usaha Anda, kegiatan apa saja yang berkaitan } \\
\hline
\end{tabular}




\begin{tabular}{|l|l|c|c|}
\hline \multirow{3}{*}{\begin{tabular}{l} 
Mengenai $\begin{array}{l}\text { Kegiatan Bisnis } \\
\text { Berkaitan } \\
\text { dengan Laporan } \\
\text { Keuangan }\end{array}$ \\
\cline { 2 - 4 }
\end{tabular}} & $\begin{array}{l}\text { Menerima pendapatan, } \\
\text { pembayaran, melakukan } \\
\text { pengeluaran (tagihan, gaji) }\end{array}$ & 14 & $56 \%$ \\
\cline { 2 - 4 } & Membuat laporan & 6 & $24 \%$ \\
\cline { 2 - 4 } & Rekap Data & 4 & $16 \%$ \\
\cline { 2 - 4 } & Produksi Barang & 1 & $4 \%$ \\
\hline & Jumlah & $\mathbf{2 5}$ & $\mathbf{1 0 0 . 0 \%}$ \\
\hline
\end{tabular}

Sumber $\quad$ : Data Primer, 2016

\section{Pembahasan Pengetahuan Laporan Keuangan}

Berdasarkan hasil penelitian, pengetahuan laporan keuangan UMKM industri konveksi secara umum dikelompokkan menjadi 4 kategori jawaban yaitu pengetahuan laporan keuangan, manfaat dan fungsi laporan keuangan,pendidikan tentang laporan keuangan yang diperoleh responden dan kegiatan bisnis yag berkaitan dengan laporan keuangan yang dapat dilihat pada tabel 2 pada kategori tentang pengetahuan laporan keuangan, terdapat 16 jawaban responden atau 64\% mengetahui laporan keuangan sebagai permbukuan yang berkaitan dengan keuangan usaha. Terkait dengan pengetahuan manfaat dan fungsi laporan keuangan, terdapat 18 jawaban responden atau $72 \%$ mengetahui manfaat dan fungsi laporan keuangan yaitu untuk melihat pemasukan, pengeluaran dan laba usaha yang diperoleh.

Penelitian ini juga menunjukkan dari banyaknya responden 11 responden atau $44 \%$ yang mengakui mengetahui banyak hal terkait laporan keuangan. Dari 11 responden, 3 responden diantaranta (12\%) mendapatkan pendidikan laporan keuangan dari pendidikan formal yaitu pelajaran sewaktu SMA. Sedangkan sisanya ada 8 responden (32\%) yang mengakui mendapat pendidikan laporan keuangan melalui pelatihan dan seminar yang diadakan dan diundang oleh Desperidag Pemerintah Kota Salatiga.Pada tabel 2 kegiatan bisnis yang berkaitan dengan laporan keuangan menunjukkan pengetahuan mengenai laporan keuangan yang ada pada usahanya, ada 56\% atau 14 responden mengetahui laporan keuangan sebagai kegiatan bisnis mereka adalah pada saat menerima pembayaran, melakukan pembayaran, melakukan pengeluaran untuk tagihan, dan membayar gaji karyawan.

Berdasarkan analisis data di atas, sebagian besar responden berpendapat bahwa secara umum laporan keuangan merupakan cara pembukuan keuangan yaitu membukukan hitungan uang atau hal yang berkaitan dengan keuangan usaha. 
Pendapat responden mengenai pengetahuannya terhadap laporan keuangan dinilai terlalu sempit dan masih mendasar karena mengingat pengetahuan laporan keuangan tidak hanya sekedar cara membukukan uang saja namun mempunyai makna yang luas. Melihat dari semua jawaban yang ada, responden mengenal laporan keuangan bukan sebagai proses pembuatan laparan keuangan yang dapat menujukan suatu performent atau kinerja suatu usaha namun sebagai cara membukukan keuangan usaha yang mereka jalankan.

Selanjutnya pengetahuan sebagian besar responden akan manfaat dan fungsi laporan keuangan adalah untuk melihat pemasukan, pengeluaran dan laba usaha. Hal tersebut menunjukkan sebagian besar responden fokus untuk mengetahui laba usahanya melalui manfaat dan fungsi laporan keuangan. Dari jawaban tersebut responden mengetahui manfaat dan fungsi laporan keuangan secara mendasar sebagai sumber informasi yang dapat digunakan untuk kepentingan usaha namun pada dasarnya manfaat dan fungsi laporan keuangan tidak hanya sebagai pemberi informasi melalui berapa besar pemasukan, pengeluaran dan laba tetapi bisa menggambarkan atau menginformasikan kinerja usahanya. Masih mendasarnya pengetahuan tentang manfaat dan fungsi akuntansi dikarenakan responden tidak menjadikan laporan keuangan hal yang penting bagi keberlangsungan usaha.

Penelitian ini menemukan bahwa UMKM industri konveksi di Salatiga masih sebatas mengenali pengetahuan laporan keuangan secara dasar. Mendasarnya pengetahuan laporan keuangan responden dikarenakan oleh beberapa alasan diduga salah satunya adalah pendidikan mengenai laporan keuangan yang diperoleh, sebagian besar mengaku tidak memiliki latar belakang pendidikan tentang laporan keuangan dan belum pernah mendapatkan pelatihan yang berkenaan dengan laporan keuangan. Di sisi lain, ironisnya responden masih beranggapan bahwa pengetahuan laporan keuangan yang dimiliki sekarang ini dirasa sudah cukup memadai untuk membantu dalam proses keberlangsungan usaha dan hal yang lebih penting bagi responden adalah dapat membayar tagihan baik bahan baku maupun pembayaran gaji pegawainya.

Sejalan dengan Gunawan (2009) mengatakan pengetahuan adalah informasi yang didapat seseorang mengenai sesuatu yang diperoleh melalui pembelajaran, pemahaman dan pengalaman.Pengetahuan laporan keuangan juga menunjukkan sikap 
kesadaran akan pentingnya peran laporan keuangan bagi pengguna.Hal ini dikarenakan laporan kinerja usaha yang terpenting adalah laporan keuangan. Karena dengan laporan keuangan pihak kreditor dapat melihat perkembangan kinerja usaha dan dapat memperkirakan kinerja usaha di masa yang akan datang. Dengan demikian maka dikaitkan hasil penelitian sewajarnya apabila responden belum secara maksimal mengembangkan usahanya masih banyak kandala yang belum dapat teratasi, responden belum mampu membuat laporan keuangan yang dapat digunakan untuk mengukur kinerja usahanya sehingga bagi pihak yang berkepentingan tidak bisa menilai kinerja usaha yang mengakibatkan tidak mau membantu memberikan pinjaman untuk modal usaha, ataupun untuk menjalin kerjasama yang berakibat memperluas pemasaran.

\section{KESIMPULAN}

Berdasarkan hasil analisis data dan pembahasan dari pendapat dan jawaban responden, pengetahuan laporan keuangan UMKM industri konveksi di Salatiga dinilai masih sebatas mengenali laporan keuangan secara mendasar. Di samping itu, sebagian besar ditemukan bahwa responden merasa yakin dengan keterbatasan pengetahuan yang mereka miliki dianggap sudah cukup memadai dan tidak perlu untuk meningkatkan kemampuan akan pengetahuan laporan keuangan.

Salah satu penyebab keterbatasan pengetahuan laporan keuagan karena mereka sebagian besar tidak mendapatkan pendidikan tentang laporan keuangan sehingga mereka tidak memahami pentingnya laporan keuangan, yang bisa berdampak pada pengembangan usanya msalnya : laporan keuangan dapat sebagai dasar untuk menambah modal yang bersumber dari lembaga keuangan. Mereka menilai bahwa yang penting bagi mereka bisa membuat dan terjual dengan hasil yang hanya bisa memenuhi kehidupan sehari hari sudah cukup untuk memenuhi kebutuhan.

\section{SARAN}

Penelitian ini memunculkan pertanyaan apakah responden yang sudah memahami laporan keuangan memiliki kemajuan usaha dibandingkan yang belum. Oleh karena itu perlu diteliti adanya hubungan pemahaman laporan keuangan dan kemajuan usaha serta akan digunakan untuk kepentingan. Selain yang disebutkan di atas, maka seyogyanya ada perhatian yang khusus dari pemerintah kota maupun lembaga lain baik dari pemerintah maupun swasta yang ditujukkan UMKM industri 
konveksi di Salatiga untuk dapat memberikan pelatihan dan wadah yang dapat mendukung pengembangan pengetahuan laporan keuangan. Karena bagaimanapun mereka merupakan penggerak perekonomian negara dan mempunyai peran penting terhadap pertumbuhan ekonomi Indonesia.

\section{DAFTAR PUSTAKA}

Amanah, S. 2012. Analisis Penerapan Pencatatan Akuntansi Pada Usaha Kecil dan Menengah Binaan Dinas Koperasi UMKM Perindustrian dan Perdagangan Kabupaten Lima Puluh Kota. Sumatera Barat. Skripsi dipublikasikan.Universitas Muhammadiyah Sumatera Barat.

Arifin, Chandra. 2010. Penerapan Akuntansi Pada Usaha Mikro Kecil dan Menengah (UMKM) Studi Kasus di Usaha Pertokoan di Jalan Jendral Sudirman Salatiga. Skripsi tidak dipublikasikan. FEB UKSW Salatiga.

Bakhtiar, Amsal. M. A. 2004. Filsafat Ilmu. Jakarta: PT. Raja Grafindo Persada..

Effendi,dkk,2012, Demokrasi Ekonomi, Koperasi dan Pengembangan Ekonomi Kerakyatan, Malang, Program Sekolah Demokrasi dan Averroes Press.

Gunawan, Ariyawan. 2009. Pengetahuan Mahasiswa Fakultas Ekonomi Universitas Kristen Satya Wacana Tentang Reksa Dana Sebagai Sarana Investasi. Skripsi tidak dipublikasikan. FEB UKSW Salatiga.

Hamid, ES, 2005, Ekonomi Indonesia dari Sentralisasi ke Desentralisasi, Yogyakarta,UII Press Yogyakarta

Hartanto, Irwin. 2010. Tanggapan Terhadap Knowledge Management Enablers Dalam Rangka Penerapan Knowledge Management. Studi Pada Institusi Pendidikan Tinggi. Skripsi tidak dipublikasikan. FEB UKSW Salatiga.

Hasan, Iqbal. 2004. Analisis Data Penelitian dengan Statistik. Jakarta: Bumi Aksara.

Ihalauw, John J.O.I. 2003. Bangunan Teori. Salatiga: FEB UKSW.

Ikatan Akutansi Indonesia ,2013, Standar Akuntansi Keuangan 2012, IAI Jakarta

Josoprijonggo, Fema Megatri. 2009. Pemahaman Mahasiswa Terhadap Obligasi Sebagai Sarana Investasi. Studi pada Mahasiswa FEB, UKSW. Skripsi tidak dipublikasikan. FEB UKSW Salatiga.

Kasmir,2002,Manajemen Perbankan,PT Raja Grafindo Persada, Jakarta.

Mamduh,M.Hanafi,2004, Manajemen Keuangan, Yogjakarta.BPFE

Munawir, S,2002, Analisa Laporan Keuangan, Liberty. Yogyakarta

Muhibbin Syah. 2003. Psikologi Belajar. Jakarta: PT Raja Grafindo.

Nitisastro, W. K. T. A. 2009. Penggunaan Business Technology Dalam Penyediaan Laporan Keuangan Perusahaan Dan Dampak Terhadap Perkembangan Usaha Studi Pada Usaha Mikro Kecil dan Menengah di Salatiga. Tesis tidak dipublikasikan. Program Pascasarjana UKSW Salatiga. 
Rahayu, Septri. 2012. Evaluasi Pembelajaran Taksonomi Bloom, Dimensi Belajar Marzano. Skripsi tidak dipublikasikan. FKIP Universitas Sriwijaya.

Rachmat F, Maya A,2004, Manajemen Perkreditan Bank Umum,Alfabeta, Bandung

Rachmawan Budiarto,dkk,2015,Pengembangan UMKM, Gadjah Mada University Press

Rizky R,Sylvia V, 2012,Kualitas Laporan Keuangan UMKM Serta Prospek Implementasi SAK ETAP,Jurnal Akuntansi dan Keuangan Indonesia Vo.9,No1, Juni 2012

Romney, M. B and Paul J. S. 2011. Sistem Informasi Akuntansi. Edisi 9 Buku 1. Jakarta: Salemba Empat.

Sagala, Syaiful. 2005. Konsep dan Makna Pembelajaran. Bandung: CV. Alfabeta.

Setia Mulyawan,2015, Manajemen Keuangan, Pustaka Setia Bandung

Soemarso. 2004. Akuntansi Suatu Pengantar. Edisi 5. Jakarta: Salemba Empat.

Sukanti. 2011. Penilaian Afektif Dalam Pembelajaran Akuntansi. Jurnal Pendidikan Akuntansi Indonesia, 74 - 8. (diunduh tanggal 22 Juli 2014).

Supramono and Damayanti, Theresia Woro. 2012. Apa Kata Mereka? Pengetahuan, Sikap dan Niat untuk Patuh Calon Pelaku Pajak. Jurnal Akuntabilitas Vol. XII No. 1 .

Supramono and Intiyas. 2003. Desain Proposal Penelitian Akuntansi dan Keuangan. FE UKSW, Satya Wacana Press, Salatiga

Sutrisno,2008, Manajemen Keuangan, Ekonisia, FE UII, Yogyakarta

Titisari., et. al. 2013. Model Pembelajaran Akuntansi Untuk Meningkatkan Kompetensi Mahasiswa. Jurnal Buletin Studi Ekonomi, Vol. 18, No. 2, Agustus 201. UNIBA. Surakarta. 